\title{
A Comparative Analysis Of Capital Expenditure On Infrastructure And Economic Growth In Nigeria And South Africa
}

\author{
R. K. Ayeni, (PhD) \\ Department of Economics \\ Ekiti State University, Ado Ekiti. \\ Ireti Olamide Olasehinde \\ Department of Economics, \\ Ekiti State University, Ado Ekiti.
}

\begin{abstract}
Nigeria and South Africa are two dominating economies in Africa but defer in terms of infrastructural development. The question of whether this infrastructural difference culminate to the difference in economic growth in the two economies is central to this study. This paper therefore, examined the impact of capital expenditure on infrastructure and economic growth both in Nigeria and South Africa using time series data from 1980 to 2016. Autoregressive Distributed Lag (ARDL) Bound tests technique of cointegration was used to on country-specific model of aggregate expenditure, following the Keynesian theory. The result showed that there is a the long-run relationship among the variables used in Nigeria and South Africa. Capital expenditure on infrastructure has positive but insignificant impact on economic growth in Nigeria while it was positive and significant on the economic growth in South Africa. The insignificant impact of capital expenditure on infrastructure on economic growth compare with South Africa may be the major difference in the two economies. This is traceable to lack of accountability and corruption in Nigeria compared to the good governance that truncated corruption and mismanagement in the government circle in South Africa. Tax base has positive and significant impacts on the economic growth in these two countries, this was supported by the Pairwise Granger Causality in which TAX granger caused economic growth in both countries. The study recommends injection of sufficient fund into infrastructural development in Nigeria. AS tax contributed positively to economic growth in both economies, it is recommended that tax revenue realized should be judiciously spent by providing the necessary amenities to discourage evasion of tax.
\end{abstract}

Key words: Capital expenditure, Infrastructure, Economic growth, ARDL Bound test, Granger causality.

\section{INTRODUCTION}

Infrastructure is an engine of economic growth which cannot be undermined in enhancing factors of production such as capital, labor and entrepreneur; and thereafter helps to increase returns on investment by reducing production cost and improving transition efficiency. The availability of infrastructural facilities and services as well as the efficiency of such services to a large extent can determine the success of production in industrialization.

In developing countries, infrastructural development has been an issue of concern to economic growth in every phase, despite the essentiality of infrastructures to life and humanity. Infrastructure cannot be undermined in creating enabling environments for achieving sustainable growth and development if well maintained. Infrastructure must be recognized as 
a fundamental part of economic growth which is expected to be incorporated by every nation in the world for economic sustainability (Fidelis, Obasanmi \& Ighata, 2014).

Investment on infrastructure is a vital driving force to achieve rapid and sustainable economic growth. The presence of sufficient infrastructure will be required for the modernization and commercialization of agriculture and the achievement of income surpluses for capital accumulation. It can provide a basis for the expansion of local manufacturing industries as well as to enlarge markets for the outputs of these industries for growth enhancing (Srinivasu \& Srinivasa, 2013). Capital expenditure on infrastructure such as road, communication, power and others reduce production costs, and increase private sector investment for profitability of firms which can be growth-enhancing (Okoro, 2013).

Economic growth in developing nations can only be facilitated and promoted by the availability and the development of infrastructure by budgeting adequately on it. Infrastructure if adequately funded is recognized as a fundamental part of economic growth which is expected to be embraced by every nation in the world especially the Africa countries for enhancing economic growth (Fidelis, et al 2014). The absence of the basic amenities in industrial sector is an injury to production at economic unit and that virtually all Nigerian infrastructures are not in good condition. The economy of South Africa is facing challenges but her capital expenditure or spending by public sector institutions has been growing steadily and notwithstanding the expenditure contributes to her GDP growth rate (Oluba, 2015; Lehohla, 2017).

This paper seeks to examine the trends in infrastructure-capital expenditure and economic growth in Nigeria and South Africa with the aim of estimating the significant relationship between capital expenditure on infrastructure and economic growth in the two countries. Analyzing causality between capital expenditure on infrastructure and economic growth in Nigeria and South Africa also important to answer the question of whether the difference in growth between the two economies is caused by infrastructural development in the countries.

\subsection{BRIEF REVIEW OF LITERATURE}

OECD, (2006), identified that, investment in infrastructures such as energy, water, irrigation, transportation and communication technologies can adequately promote economic growth and help to alleviate poverty and improve living conditions in developing countries. To this, many countries have increased their expenditures on infrastructure.

Alfonso and Alessandro (2008) examined an estimation of the long and short-run relations between government expenditure and potential output across EU countries. Panel cointegration test was used to reveal that government expenditure and potential output in the EU were linked by a stable long-run relation.

The study by Jiranyakul and Brahmasrene (2007) reviewed by Kalu and Raphael (2016) examined the relationship between government expenditures and economic growth in Thailand for the period of 1993 and 2006 using Standard Granger Causality test and Ordinary Least Square (OLS) method. The results showed a unidirectional causality from government to economic growth. Furthermore, estimation from the ordinary least square confirmed the strong positive impact of government expenditure on economic growth during the period of investigation. 
Modebe, Regina, Okafor and Onwumere (2012) examined the impact of recurrent and capital expenditure on Nigerian economic growth by using three variables multiple regression model. The result emanating from this study revealed that while recurrent government expenditure had positive and non-significant impact on economic growth, capital expenditure had negative and non-significant impact on economic growth which emphasized the need for increase and encouragement of private sector investment.

Okoro, (2013), also confirmed that capital expenditure is a necessary across the world for procuring good and adequate infrastructure (roads, communication, power and others) needed for creating enabling environment and to reduce production costs as well as to increase private sector investment for profitability of firms for economic growth.

Loto, (2011), said that economic growth brings about a better standard of living to the people through provision of better infrastructure, health, housing, education services and improvement in agricultural productivity and food security.

Onakoya and Somoye (2013) examined the impact of public capital expenditure and economic growth in Nigeria using three stage least squares (3SLS) technique and macro-economic model of simultaneous equation. The study showed that public capital expenditure contributed positively to economic growth in Nigeria within the stipulated time series. The results however confirmed that public capital spending indirectly enhanced economic growth by encouraging private sector investment due to the facilitating role of government in the provision of public goods.

Meyer, Manete and Muzindutsi (2017) examined the effect of government expenditure and sectional investment on economic growth in South Africa, using Vector Autoregressive (VAR) model to analyze the impact of government spending and investment in economic sectors on economic growth, thereafter Vector Error Correction Model (VECM) exhibited that only investment in the financial sector has a significant effect on economic growth and the long-run results showed that only investment in manufacturing sector had a positive effect on economic growth but the effect of government spending on economic growth was found to be insignificant.

\section{THEORETICAL FRAMEWORK}

The three (3) main economic growth theories over time that have attempted to increase the trends of GDP upward are Classical theory of economic growth, Neo-classical theory of economic growth and Modern theory of economic growth. GDP is used to compare the economic growth among the nations. The production of citizens or foreign-owned companies residing in a nation is GDP (Kallie, 2016). Keynes (1936) categorized public expenditure as an exogenous variable that can generate economic growth instead of endogenous phenomenon. He believed the role of the government to be crucial as it can avoid depression by increasing aggregate demand and thus, switching on the economy again by the multiplier effect. Keynesian school of thought believed that public expenditure can contribute positively to economic growth. Keynes (1936) believed that public expenditure is a tool that brings stability in the short-run but this needs to be done cautiously as too much of it leads to inflationary situations while too little of it leads to unemployment, meaning public expenditure must be moderate.

Keynes believed that government played an important role in the determination of the aggregate expenditure (AE) in an economy and thus included government expenditure in the aggregate expenditure function as 


$$
\mathrm{AE}=\mathrm{C}+\mathrm{I}+\mathrm{G}+\mathrm{NX}
$$

Infrastructure-based economic development known as infrastructure driven development combines key policy characteristics inherited from Roosevelt progressivist tradition and NeoKeynesian economics in the United States, France's Gaullist and Neo-Colbert's on centralized on economic planning. It holds that a substantial proportion of a nation's resources be systematically directed towards long term assets such as transportation, energy and social infrastructure (schools, universities, hospitals and others). The theory is modeled as $\mathrm{Y}=\mathrm{f}(\mathrm{K}, \mathrm{G}$, $\mathrm{N}, \mathrm{Z}$ ), where $\mathrm{Y}=$ level of output, $\mathrm{K}=$ fixed capital, $\mathrm{G}=$ level of government services, $\mathrm{N}=$ population, $\mathrm{Z}=$ index of technological progress.

\section{DATA AND METHODOLOGY}

The model for this study was originated from Keynesian aggregate expenditure model and infrastructure-based development model being the revised version of Odo et al., (2016) as thus;

$$
\text { GDP }_{i t}=f\left(C A P E X_{i t}, I^{\prime N V T} T_{i t}, N X_{i t}, P_{i t,} \text { TAXit, TLFit }\right)
$$

Where;

$\mathrm{i}=$ individual country (Nigeria and South Africa)

$\mathrm{t}=$ time series $=(1980-2016)$

GDP $=$ Gross Domestic Product proxy by GDP growth rate.

CAPEX = Capital expenditure on infrastructure.

INVT = Investment proxy by Foreign direct investment.

$\mathrm{NX}=$ Net exports (exports - imports).

$\mathrm{POP}=$ Population.

TAX = Tax on GDP ratio proxy by tax revenue ( $\%$ of GDP).

TLF $=$ Total Labor force.

The model (2) is to estimate the parameters of the co-integration analysis;

$$
g d p_{i t}=\alpha_{0}+\alpha_{1} \operatorname{capex}_{i t}+\alpha_{2} \text { invt }_{i t}+\alpha_{3} n x_{i t}+\alpha_{4} \operatorname{pop}_{i t}+\alpha_{5} \operatorname{tax}_{i t}+\alpha_{6} t l f_{i t}+e_{i t} \ldots 2
$$

Where;

$\alpha_{0}=$ constant intercept

$\alpha_{1}$ to $\alpha_{6}=$ regression coefficients \& parameters to be estimated.

$u_{i t}=$ stochastic or residual trend.

RESULTS AND DISCUSSIONS

Table 1: Descriptive statistics of variables (Nigeria).

\begin{tabular}{|l|l|l|l|l|l|l|}
\hline Variables & Mean & Std. Dev. & Skewness & Kurtosis & Jarque-bera & Prob. \\
\hline GDPGR & 3.542640 & 7.506881 & 1.229810 & 8.924161 & 63.43250 & 0.00000 \\
\hline CAPEX & 13.40631 & 7.335984 & 1.906930 & 6.323949 & 39.45767 & 0.00000 \\
\hline FDI & 2.844273 & 2.326692 & 1.558264 & 5.990852 & 28.76433 & 0.00001 \\
\hline$N X$ & 9.054204 & 8.205982 & 0.597468 & 3.719839 & 3.000141 & 0.223114 \\
\hline POP & 0.0012131 & 33.398806 & 0.350347 & 1.954117 & 2.443302 & 0.294743 \\
\hline TAX & 5.193234 & 2.180733 & 0.824295 & 2.805238 & 4.248491 & 0.119523 \\
\hline TLF & 36.940905 & 10.798622 & 0.200622 & 1.959835 & 1.916198 & 0.383621 \\
\hline
\end{tabular}

Source: Author's Computation, 2020

In Table 1, the results of the estimated mean value which is used to examine the nature of the data distribution, recorded the highest mean value of (36.940905) for Total Labor Force (TLF) in Nigeria while Population (POP) has the lowest mean value of 0.0012131. Standard deviation 
in its own case showed that Foreign Direct Investment (2.326692), Tax revenue (2.180733), GDP growth rate (7.506881), Capital expenditure (7.335984) and Net export (8.205982) as they have low standard deviation values. This is an indication that these variables showed very low variability in Nigeria. But this is different for other variables like Population (33.398806) and Total Labor Force (10.798622) as they showed high variability in Nigeria. The results equally showed that all the variables of interest are positively skewed.

The estimated values of Kurtosis for GDPGR, CAPEX, FDI and NX are greater than 3 which indicate that the distribution of these variables is thicker and therefore implies the presence of heterogeneity issues in their data. The Kurtosis values of POP, TAX and TLF are lesser than 3, implying that the tails of the distribution for these variables are thinner than the normal distribution. The Jarque-bera which measures the normality of the variables ranged from 1.916198 (TAX) to 63.43250 (GDPGR). The results of the descriptive statistics therefore justified the use of Autoregressive Distributed Lag tests (ARDL) to estimate the relationships among the variables in this study, judging by the presence of heterogeneity in the data series in Nigeria.

Table 2: Descriptive statistics of variables in South Africa.

\begin{tabular}{|l|l|l|l|l|l|l|}
\hline Variables & Mean & Std. Dev. & Skewness & Kurtosis & Jarque-bera & Prob. \\
\hline GDPGR & 2.350320 & 2.299820 & -0.288562 & 2.245101 & 1.392041 & 0.498565 \\
\hline CAPEX & 20.06885 & 3.899366 & 0.930879 & 3.064743 & 5.350102 & 0.068903 \\
\hline FDI & 0.914341 & 1.2774113 & 2.038722 & 8.023909 & 64.54220 & 0.00000 \\
\hline$N X$ & 2.172785 & 3.220920 & 0.635973 & 2.599967 & 2.740886 & 0.253994 \\
\hline$P O P$ & 443.48033 & 78.52536 & -0.163024 & 1.809160 & 2.350130 & 0.308799 \\
\hline TAX & 23.59646 & 2.396140 & -0.167610 & 2.303936 & 0.920186 & 0.631225 \\
\hline$T L F$ & 155.29057 & 33.67214 & 0.182365 & 1.712227 & 2.761720 & 0.251362 \\
\hline
\end{tabular}

Source: Researchers' Computation (2020)

Table 2 showed the descriptive statistics of variables in South Africa. The results of the estimated mean value ranged from 0.914341(FDI) to 443.48033 (POP) in South Africa. A critical examination of standard deviation of variables in South Africa showed that GDPGR (2.299820), CAPEX (3.899366), FDI (1.274113), NX (3.220920) and TAX (2.396140) were of low variability, but POP (73.52536) and TLF (33.67214).

CAPEX, FDI, NX and TLF are positively skewed while GDPGR, POP and TAX are negatively skewed in South Africa. The estimated Kurtosis values for CAPEX and FDI are greater than 3, implying the peakedness of the distribution while GDPGR, NX, TAX and TLF are less than 3, indicating the flatness of the normal distribution in South Africa. The Jarque-bera which measures the normality of the distribution ranged from 0.920186 to 64.54220 .

From the descriptive statistics of the variables, it is also observed the mean for Nigeria ranged from 0.001213 (POP) to 36.940905 (TLF) whereas the mean for South Africa ranged from 0.914341 (FDI) to 443.48033 (POP). The standard deviation from both countries showed low values (low variability) and high values (high variability). In term of the skewness, all variables in Nigeria were positively skewed which gives better knowledge of the distribution than that of South Africa having positive and negative skewness. The values from kurtosis showed peakedness and flatness of the distribution in both countries. 
Figure 1: Trends of GDPGR in Nigeria and South Africa
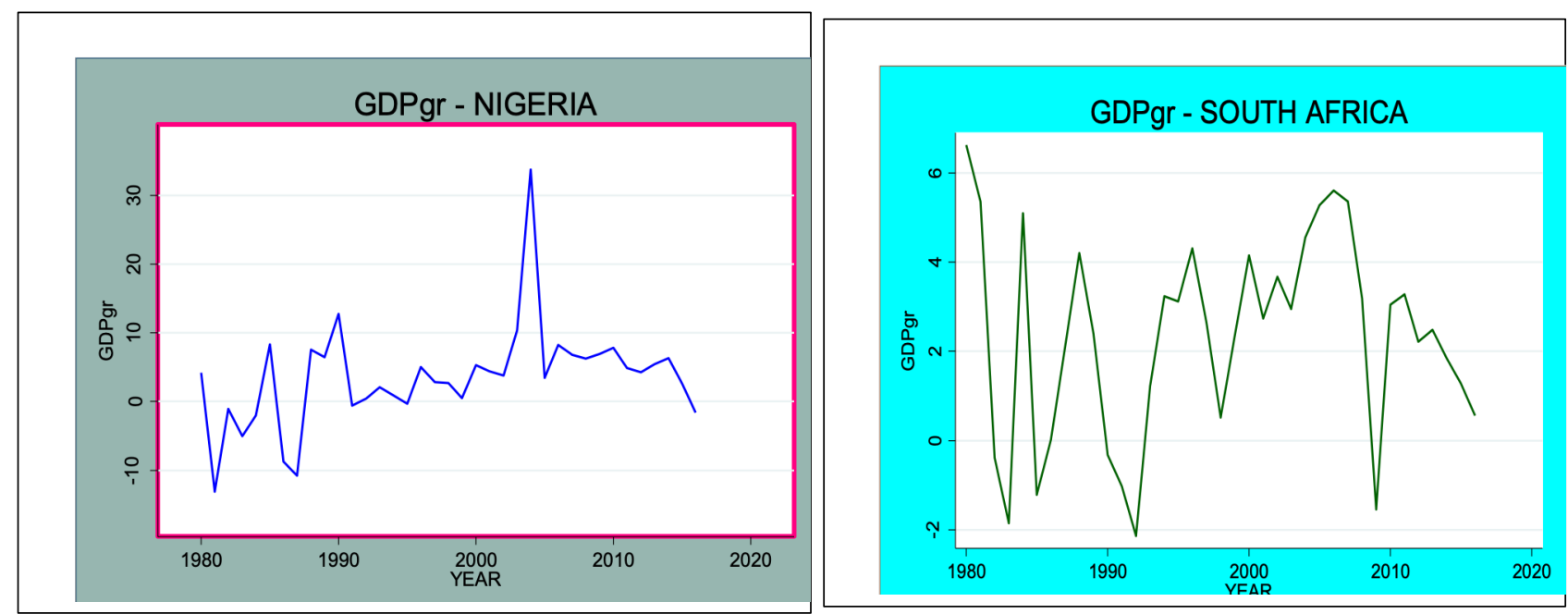

Figure 1 showed the trends of GDPGR in Nigeria and South Africa compared. From the graphs, it is revealed that the GDP growth rate series in Nigeria maintained a fluctuation pattern from 1980 to 1999 and thereafter made upward trend from 2001 to 2005 . The upward movement in the Nigerian GDP growth rate during this period might be due to the healthy institutional and economic policies put in place to stimulate the country economy as a result of the dividend of democratic government enjoyed since 1999. However, the decline witnessed from 2007 is as a result of the economic recession that hit the Nigerian economy. Minimum growth within the period was below -10. The figure also reveals that the GDP growth rate of South Africa exhibited a fluctuating pattern as it did not maintain consistent trend between 1980 and 2016 .

Figure 2: Trends of CAPEX in Nigeria and South Africa.
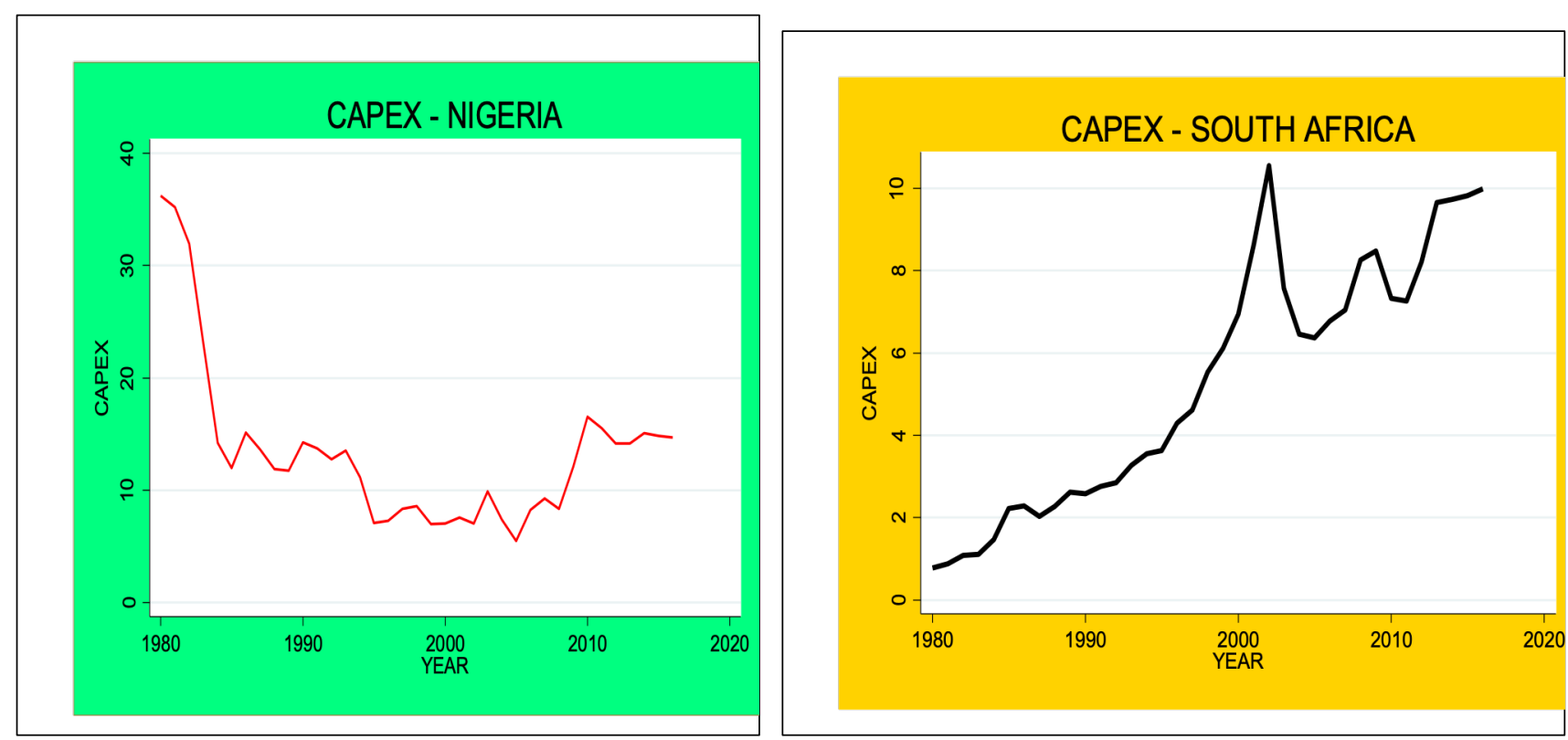

Minimum growth observed within the period was about -2.0. it is to be noted that South Africa witnessed more period of growth decline than Nigeria.

The line graph in figure 2 showed the trends of CAPEX in Nigeria and South Africa compared. 
The figure exhibited that CAPEX in Nigeria witnessed a downward trend between 1980 and 1985 after which it started to fluctuate up to 2010. Nigeria again experienced a significant rise in its CAPEX from 2013 throughout the remaining periods which was largely due to the government budgetary expenditure on security and insurgency menace in the country. The figure also revealed an upward trend pattern of CAPEX for South Africa from 1980 to 2000 after which it began to wander up and down. The significant upward trend of CAPEX in South Africa was largely pronounced in the 1990s. This might be largely due to the government expenditure during the end of foreign rule and introduction of democratic governance to speed up social service delivery for the black population after many years of deprivation and neglect. Comparison shows that South Africa has a higher trend in capital expenditure on infrastructure than Nigeria.

In Nigeria and South Africa, capital expenditure on infrastructure (CAPEX) and economic growth (GDPGR) covering a period of 37 years can be compared in direction of the levels of infrastructural provision, development and economic growth of each country. In 80s, CAPEX in Nigeria witnessed a downward trend while that of South Africa witnessed an upward trend. Nigeria GDP Growth rate ranged from 4.2\% to $-1.6 \%$ between 1980 and 2016 while South Africa GDP Growth rate ranged from $6.6 \%$ to $0.6 \%$ within the same period, showing that Nigerian economy witnessed recession $(-1.6 \%)$ while the economy of South Africa witnessed a growth of $0.6 \%$ as at 2016 .

The next sub-section reports the results of the Unit root Test and the Cointegration Analysis.

The Philip-Peron unit root results in Table 3 established that GDPGR, CAPEX, FDI, NX were stationary at level, [I(0)] and POP, TAX, TLF were stationary at $1^{\text {st }}$ difference [I(1)] for Nigeria. This is also witnessed for South Africa except CAPEX which is stationary at first difference for South Africa. The condition for Johansen Cointegration technique is not met, therefor we resort to the ARDL Bound Cointegration Test.

Table 3: Philip Peron Unit root Test on Variables

\begin{tabular}{|c|c|c|c|}
\hline \multicolumn{5}{|c|}{ NIGERIA } \\
\hline Variable & PP-Statistic & Critical Value & I(p) \\
\hline GDPGR & -4.545586 & -3.626784 & $\mathrm{I}(0)$ \\
\hline CAPEX & -3.941646 & -3.626784 & $\mathrm{I}(0)$ \\
\hline FDI & -3.647316 & -3.626784 & $\mathrm{I}(0)$ \\
\hline NX & -4.355672 & -3.626784 & $\mathrm{I}(0)$ \\
\hline D(POP) & -3.81401 & -3.6329 & $\mathrm{I}(1)$ \\
\hline D(TAX) & -4.237061 & -3.6329 & $\mathrm{I}(1)$ \\
\hline D(TLF) & -3.163146 & -2.948404 & $\mathrm{I}(1)$ \\
\hline \multicolumn{5}{|c|}{ SOUTH AFRICA } & \\
\hline GDPGR & -4.344879 & -3.626784 & $\mathrm{I}(0)$ \\
\hline D(CAPEX) & -3.917539 & -3.6329 & $\mathrm{I}(1)$ \\
\hline FDI & -4.410421 & -3.626784 & $\mathrm{I}(0)$ \\
\hline NX & -3.039575 & -2.945842 & $\mathrm{I}(0)$ \\
\hline D(POP) & -2.127376 & -1.951 & $\mathrm{I}(1)$ \\
\hline D(TAX) & -7.213039 & -3.6329 & $\mathrm{I}(1)$ \\
\hline D(TLF) & -4.505298 & -3.6329 & $\mathrm{I}(1)$ \\
\hline
\end{tabular}


Table 4 shows the results of ARDL Bound Cointegration test for the two countries. The Null Hypothesis is that there is no long-run relationship existing among the variables. From the results, it is revealed that the computed F-statistics value of 8.162675 for Nigeria and 14.24316 for South Africa are respectively greater than the Upper Bound values at any level of significance. The null hypothesis is rejected and implying that there is long-run relationship among all the variables during the period under review for the two countries. The long run and short run models for the two countries are presented in Tables 5.

Table 4: Pesaran ARDL Bound Co-integration Test Results (Nigeria)

\begin{tabular}{|l|c|c|}
\hline & F-stat. Value & $\mathrm{K}$ \\
\hline South Africa & 14.24316 & 6 \\
\hline Nigeria & 8.162675 & 6 \\
\hline \multicolumn{2}{|c|}{ Critical Value Bounds } \\
\hline Level of significance & $\mathrm{I}(0)$ Bound & $\begin{array}{c}\mathrm{I}(1) \\
\text { Bound }\end{array}$ \\
\hline $10 \%$ & 2.12 & 3.23 \\
\hline $5 \%$ & 2.45 & 3.61 \\
\hline $2.50 \%$ & 2.75 & 3.99 \\
\hline $1 \%$ & 3.15 & 4.43 \\
\hline
\end{tabular}

Source: Author's Computation, 2020

Table 5: ARDL Cointegration and Long-run Form Results (Nigeria and South Africa)

\begin{tabular}{|c|c|c|c|c|}
\hline \multicolumn{5}{|c|}{ Short - run Model } \\
\hline Variables & \multicolumn{2}{|c|}{ Nigeria } & \multicolumn{2}{c|}{ South Africa } \\
\hline GDPGR & Coefficient & Probability & Coefficient & Probability \\
\hline D(CAPEX) & 0.377558 & 0.1909 & 0.377868 & 0.0153 \\
\hline D(FDI) & 0.158125 & 0.7681 & -0.059961 & 0.0078 \\
\hline D(NX) & 0.027258 & 0.8417 & 0.629043 & 0.2042 \\
\hline D(POP) & 0.1686102 & 0.0036 & 0.162421 & 0.0176 \\
\hline D(TAX) & 4.494907 & 0.0024 & 0.807732 & 0.0283 \\
\hline D(TLF) & 0.086876 & 0.6402 & 0.214241 & 0.1031 \\
\hline Coint Eq(-1) & -1.181298 & 0.0000 & -1.019459 & 0.0000 \\
\hline \multicolumn{5}{|c|}{ Long-Run Model } \\
\hline Variables & Coefficient & Probability & Coefficient & Probability \\
\hline CAPEX & 0.319613 & 0.1858 & 0.426524 & 0.0237 \\
\hline FDI & 0.133857 & 0.8692 & -0.058816 & 0.0178 \\
\hline NX & 0.023074 & 0.8417 & 0.173075 & 0.2324 \\
\hline POP & 0.268101 & 0.2717 & 0.212414 & 0.1041 \\
\hline TAX & 2.425175 & 0.0315 & 0.119667 & 0.0052 \\
\hline TLF & 0.41625 & 0.1157 & 0.244324 & 0.2149 \\
\hline R-squared & 0.740723 & & 0.756016 & \\
\hline Prob(F-statistic) & 0.001482 & & 0.000017 & \\
\hline \multicolumn{5}{|c|}{ Source Author } \\
\hline
\end{tabular}

Source: Author's Computation 
The Error Correction Mechanism (Coint.Eq(-1)) in Table 5 is negative for both countries, indicating that the adjustment to equilibrium is in the right direction. The Error Correction term with the coefficient $(-1.181298)$ and the p-value $(0.0000)$ for Nigeria and $(-1.019459)$ for South Africa, also significant showed a long-run causality between endogenous variables and the endogenous variable. The ECM is capable of correcting any deviation of the short-run dynamics to its long-run equilibrium. This implies that there is disequilibrium in economic growth in Nigeria and South Africa respectively, which the exogenous variables are trying to adjust in the short run. The adjustment is in the right direction to restore equilibrium in economic growth in the long run.

The magnitude of the ECM is 1.1813 for Nigeria. this implies that the speed of adjustment is about $118 \%$ per period. It is 1.0194 for South Africa implying that about $102 \%$ of the disequilibrium is restored per period. These are very high speed of adjustment in each country, given that our focus variable, capital expenditure on infrastructure is significant. Unfortunately, capital expenditure on infrastructure is only significant in South Africa to adjust economic growth towards positive equilibrium in the short run. It is not significant in Nigeria. This may be due to the poor infrastructures witnessed in Nigeria. A good comparison is the transportation through railway which is still very active in South Africa but has moribund in Nigeria.

Taxation variable impacts positively on the two economies in the short run as well as in the long run. This implies that if the right taxation structure is adopted in these two economies, there is the tendency to increase economic growth in the long run. Population variable has not significantly affected economic growth in the two countries. This may be due to the fact that the structure of population in the two countries is less of working population. The computed coefficients of multiple determination $\left(\mathrm{R}^{2}\right)$ value of 0.74 for Nigeria and 0.76 for South Africa indicates that the model in the study satisfied the requirement for goodness of fit. The $\mathrm{f}$ statistics p-value of 0.001482 which is less than $5 \%$ showed that the influence of all the explanatory variables on GDPGR is statistically significant, indicating that the independent variables have a joint influence on the GDPGR.

The short-run segment of the results indicates that CAPEX, FDI, POP and TAX exerted significant impacts on GDPGR in South Africa. Out of these four variables, only FDI exhibited negative and significant impact on GDPGR while CAPEX, POP and TAX have positive and significant impacts on GDPGR. From the short-run segment result, NX and TLF have positive and insignificant impacts on GDPGR. In the case of long-run model, CAPEX, FDI and TAX have significant impacts on GDPGR while the other variables such as NX, POP and TLF have insignificant impacts on GDPGR.

Table 6 showed that unidirectional causality was observed as thus; GDPGR granger caused CAPEX, GDPGR granger caused FDI, GDPGR granger caused NX, POP granger caused GDPGR and TAX granger caused GDPGR while other variables showed no causality.

The results corroborate the results of the short and long-run estimation regression in which these variables (i.e. CAPEX, FDI, and NX) did not impact significantly on GDPGR in Nigeria. 
Table 6: Pairwise Granger Causality Test Results (Nigeria)

\begin{tabular}{|c|c|c|c|}
\hline Null Hypothesis & F-statistics & Probability & Decision \\
\hline CAPEX does not Granger cause GDPGR & 1.30351 & 0.2865 & Accept \\
GDPGR does not Granger cause CAPEX & 6.68652 & 0.0051 & Reject \\
\hline FDI does not Granger cause GDPGR & 0.39494 & 0.6772 & Accept \\
GDPGR does not Granger cause FDI & 5.89254 & 0.0074 & Reject \\
\hline NX does not Granger cause GDPGR & 0.33945 & 0.7149 & Accept \\
GDPGR does not Granger cause NX & 4.33023 & 0.0068 & Reject \\
\hline POP does not Granger cause GDPGR & 4.09809 & 0.0034 & Reject \\
GDPGR does not Granger cause POP & 1.40604 & 0.2608 & Accept \\
\hline TAX does not Granger cause GDPGR & 6.77664 & 0.0275 & Reject \\
GDPGR does not Granger cause TAX & 0.85085 & 0.4371 & Accept \\
\hline TLF does not Granger cause GDPGR & 0.8628 & 0.6032 & Accept \\
GDPGR does not Granger cause TLF & 2.28014 & 0.1197 & Accept \\
\hline NX does not Granger cause CAPEX & 0.7264 & 0.1142 & Accept \\
CAPEX does not Granger cause NX & 0.79412 & 0.4613 & Accept \\
\hline TAX does not Granger cause CAPEX & 0.1515 & 0.1015 & Accept \\
CAPEX does not Granger cause TAX & 2.46225 & 0.1022 & Accept \\
\hline TLF does not Granger cause CAPEX & 0.61713 & 0.1064 & Accept \\
CAPEX does not Granger cause TLF & 2.46826 & 0.1026 & Accept \\
\hline FDI does not Granger cause CAPEX & 0.19253 & 0.3421 & Accept \\
CAPEX does not Granger cause FDI & 0.413411 & 0,1941 & Accept \\
\hline
\end{tabular}

Table 7: Pairwise Granger Causality Test Results (South Africa)

\begin{tabular}{|c|c|c|c|}
\hline Null Hypothesis & F-statistics & Probability & Decision \\
\hline CAPEX does not Granger cause GDPGR & 4.11464 & 0.0264 & Reject \\
GDPGR does not Granger cause CAPEX & 8.8936 & 0.0005 & Reject \\
\hline FDI does not Granger cause GDPGR & 6.56339 & 0.0052 & Reject \\
GDPGR does not Granger cause FDI & 2.43891 & 0.1044 & Accept \\
\hline NX does not Granger cause GDPGR & 0.83302 & 0.1174 & Accept \\
GDPGR does not Granger cause NX & 0.36822 & 0.695 & Accept \\
\hline TAX does not Granger cause GDPGR & 3.26965 & 0.0035 & Reject \\
GDPGR does not Granger cause TAX & 3.70304 & 0.0365 & Reject \\
\hline POP does not Granger cause GDPGR & 2.60318 & 0.0907 & Accept \\
GDPGR does not Granger cause POP & 2.14489 & 0.1347 & Accept \\
\hline TLF does not Granger cause GDPGR & 0.29423 & 0.609 & Accept \\
GDPGR does not Granger cause TLF & 0.1099 & 0.8963 & Accept \\
\hline NX does not Granger cause CAPEX & 0.11058 & 0.1238 & Accept \\
CAPEX does not Granger cause NX & 0.91931 & 0.1068 & Accept \\
\hline TAX does not Granger cause CAPEX & 6.88124 & 0.0047 & Reject \\
CAPEX does not Granger cause TAX & 0.60051 & 0.555 & Accept \\
\hline TLF does not Granger cause CAPEX & 0.33552 & 0.7076 & Accept \\
CAPEX does not Granger cause TLF & 1.31284 & 0.2841 & Accept \\
\hline
\end{tabular}


Table 7 established that bi-directional causality exists between CAPEX \& GDPGR, as well as TAX \& GDPGR while unidirectional causality was observed as thus, FDI granger caused GDPGR, POP granger caused GDPGR and TAX granger caused CAPEX and the rest variables have no causality. Therefore, CAPEX granger caused GDPGR in this estimation is a strong alignment with the results got from the short and long-run estimation regression in which CAPEX impacts positively and significantly on the GDPGR in South Africa.

This section compares the results of the all the tests conducted in this study. The results from ARDL Bound test confirmed a long-run significant relationship among the variables in the models in Nigeria and South Africa. Both the short and long-run segments of the ARDL Cointegrating and Long-run regression established that CAPEX has positive but insignificant impact on GDPGR in Nigeria, which might happen through corruption and mismanagement by the authority in charge. This finding is aligned with the results from Pairwise granger causality in which only the GDPGR that granger caused CAPEX while CAPEX could not granger cause GDPGR. There is tendency for government spending to increase proportionately which is in line with the report of (Felix and Sabtis, 2014). However, from the results of ARDL test and Pairwise granger causality test for South Africa, the findings from the two tests revealed that CAPEX and GDPGR have positive and significant impacts on each other, collaborating the results of Ebongs et al., (2012).

In addition, the ARDL tests revealed that FDI has positive but insignificant impact on GDPGR in Nigeria which is in line with Pairwise granger causality test as FDI failed to granger cause both GDPGR and CAPEX. This insignificant impact of FDI on both GDPGR and CAPEX might be attributed to the insufficient FDI fund invested into the Nigerian economy. This finding really corroborates the assertion of Egbo (2010). In comparison, the results of South Africa showed that the impact of FDI on GDPGR though significant but negative on her economy. This finding might be connected with insufficient capital expenditure being made in South Africa compared with capital expenditure in Nigeria.

Another very important finding from this study is that ARDL cointegration tests for both Nigeria and South Africa ascertained that TAX has positive and significant impacts on the GDPGR of the two countries which is in line with the results of Pairwise granger causality for the two countries in which TAX granger caused GDPGR. The economic implication of these findings is that tax revenue has a very high impact on the economic growth of Nigeria and South Africa as a source of revenue available to the government of both countries for the purpose of growth and development, with conformity with the reports of Hall (1993) and Brian (2007). But in spite of the revenue accrued to the government of Nigeria, the state of infrastructures and social amenities are still not impressive, which corroborates the reports of (Adegbie \& Fakile, 2011).

\section{CONCLUSION}

Having examined empirically the impact of infrastructure-capital expenditure on economic growth, it can be concluded, based on the results and discussion of findings that there existed long-run relationship between capital expenditure on infrastructure and economic growth in these two countries. Both at the short-run and long-run, (ARDL) cointegration confirmed that capital expenditure has insignificant positive impact on economic growth in Nigeria, but showed significant positive impacts on GDPGR in South Africa. Foreign direct investment (FDI) has positive but insignificant impact on economic growth in Nigeria, while FDI has negative but significant impact on the South African economy. Tax base (TAX) has positive and significant impacts on the economic growth of both countries (Nigeria and South Africa). It is recommended that capital expenditure on infrastructure should be increased by allocating 
adequately in yearly budgetary to give room for creating enabling environment for the essentiality of man and for adequate structuring and restructuring of the economy.

\section{References}

Adegbite, F. \& Fakile, T. (2011). Customs and excise duties contribution towards the development and growth of Nigerian economy. European Journal of Economics, Finance and Administrative Sciences, ISSN:1450-2275, Issue 29.

Alfonso, A., \& Alessandro, T. (2008). Government expenditure and economics growth in the EU: Long-term tendencies and short-term adjustment. Retrieved from http://europa.eu

Brian, M. (2007). Effects of tax revenue on economic growth: Uganga's experience. Journal of Accounting and Tax Revenue, 1(1), 8-22.

Ebong, F., Ogwumika, F., Usongwo, U., \& Ayodele, O. (2012). Impact of government expenditure on economic growth in Nigeria: A disaggregated analysis.

Fidelix, O. \& Sabtis, A. (2014). Government spending and national income: A time series and panel analysis for Nigeria, Ghana and South Africa. Research Journal of Finance and Accounting, 5(14), 21-32.

Fidelis, O. N., Obasanmi, J. O., \& Igbata, J. A. (2014). Infrastructural development growth in Nigeria. Journal of Economics, 5(3), 325-332.

Hall, B. H. (1993). Research and development tax policy during the 1980s: Success or failure? In tax policy and the economy, edited by James Poterba, Cambridge, MA: MIT Press

Kalu, I. A., \& Raphael, O. C. M. (2016). An empirical analysis of the effect of government expenditure on economic growth in Nigeria (1981-2013). Research Journal of Finance \& Accounting, 7(20).

Keynes, J. M. (1936). The general theory of employment, interest, and money, Harcourt brace and Co., New York.

Lehohla, P. (2017). Eskom leads spending on capital expenditure in 2016. Retrieved from https://www.timeslive.com.

Loto, M. A. (2011). Impact of government sectoral expenditure on economic growth. Journal of Economics and International Finance, 3(11), 646-652.

Meyer, D. F., Manete, T., \& Muzindutsi, P. F. (2017). The Impact of government expenditure and sectional investment on economic growth in South Africa.

Modebe, N. J., Regina, G., Okafor, J. U. J., \& Onwumere, I. G. I. (2012). Impact of recurrent and capital expenditure on Nigerian Economy Growth. European Journal of Business and Management.

Odo, S. I., Igberi, C. O., Udude, C. C., \& Chukwu (2016). Public expenditure and economic growth in South Africa: Long run and causality approach. Asian Journal of Economics, Business \& Accounting, 1(2).

Okoro, A. S. (2013). Government expenditure and economic growth.

Oluba, M. (2015). Who should provide public infrastructure in Nigeria? Available at http://www.martinoluba.com/publications.jsp

Onakoya, A. B. \& Somoye, R. O. C. (2013). The impact of public expenditure and economic growth in Nigeria. Global Journal of Economics and Finance, 2(1).

OECD (2006), Organization for Economic Cooperation \& Development. (2006). Infrastructure 2030:

Telecommunication, land transport, water and Electricity.

Srinvivasu, B. \& Srinivasa, R. P. (2013). Infrastructure development and economic growth; Prospects and perspective. Journal of Business Management and Social Sciences Research (JBM \& SSR), 2(1). 